\title{
Technology, social space and environmental justice in Swedish cities: Water distribution to suburban Norrköping and Linköping, 1860-90
}

Jonas Hallström

\author{
Linköping University Post Print
}

Tweet

N.B.: When citing this work, cite the original article.

Original Publication:

Jonas Hallström, Technology, social space and environmental justice in Swedish cities: Water distribution to suburban Norrköping and Linköping, 1860-90, 2005, Urban History, (32), 3, 413-433.

http://dx.doi.org/10.1017/S0963926805003214

Copyright: Cambridge University Press (CUP)

http://www.cambridge.org/uk/

Postprint available at: Linköping University Electronic Press

http://urn.kb.se/resolve?urn=urn:nbn:se:liu:diva-50370 


\title{
Technology, Social Space and Environmental Justice in Swedish Cities: Water Distribution to Suburban Norrköping and Linköping, 1860-18901
}

\author{
Jonas Hallström
}

\begin{abstract}
The aim of this article is to study how the Swedish cities Linköping and Norrköping treated new working-class suburbs during the period from 1860 to 1890 , by looking at the extension of piped water supply. The author concludes that working-class suburbs were located in poor, geographically unfavourable and unsanitary places, to which extensions of water could be technically demanding and expensive, which led to frequent urban inability or unwillingness to help. It is also suggested that by denying water cities separated spatially between city and suburb, thereby underlining already existing environmental and even spatial injustice between the two.
\end{abstract}

The advent of the modern, industrial age in the early to mid-1800s brought great changes to urban Europe, notably substantially increased city growth. ${ }^{2}$ On the European periphery, for

\footnotetext{
${ }^{1}$ Some of the research on which this article is based has also provided material for J. Hallström, 'The growing pains of the pipe-bound city: the extension of water and sewerage to suburban areas in Norrköping, Sweden, 1860-1890', Public Works Management \& Policy, 6, 3 (2002), 186-99 and J. Hallström, Constructing a PipeBound City: A History of Water Supply, Sewerage, and Excreta Removal in Norrköping and Linköping, Sweden, 1860-1910 (Linköping 2002), part II. The author wishes to thank Professor Marie C. Nelson and the anonymous readers for proofreading and commenting on earlier versions of the manuscript.

${ }^{2}$ P. M. Hohenberg and L. H. Lees, The Making of Urban Europe 1000-1994 (Cambridge 1995), 8-11. The relationship between industrialization and urbanization is complicated, which, for instance, the local examples of Norrköping and Linköping show. Although not an industrial town, Linköping's population grew faster than Norrköping's in the very late nineteenth century, as Table 1 shows: Hallström, Constructing a Pipe-Bound City,
} 
example, in Scandinavia, cities and towns were still generally very small, often resembling villages, although some cities began growing rapidly (see Table 1). ${ }^{3}$ In Swedish towns congestion and unsanitary conditions prevailed despite their relative smallness, so in the midto late nineteenth century modern city planning was introduced, inspired by influential British public health administrator Edwin Chadwick and Paris urban reformer Georges Haussmann. The urban environment was to be improved with water supply and sewer systems and by creating rural sanctuaries within towns, which can be seen in legislation as well as in practice, for example, in Stockholm and Norrköping. In architecture and planning light, fresh air and gardens were seen as remedies for the degraded modern urban landscape. ${ }^{4}$

29-30. Rural population growth, which led to in-migration to Swedish cities, and nativity surplus in the cities, were as important as industrialization in bringing about urbanization: L. Nilsson, Den urbana transitionen. Tätorterna i svensk samhällsomvandling 1800-1980 (Stockholm 1989).

${ }^{3}$ C. af Forsell, Statistik öfver Sverige grundad på offentliga handlingar (Stockholm 1833); J.-O. Drangert and J. Hallström, 'Den urbana renhållningen i Stockholm och Norrköping: från svin till avfallskvarn?', Bebyggelsehistorisk tidskrift, 44 (2002), 7-24; Cf. A. Imhof, Der agrare Charakter der schwedischen und finnischen Städte im 18. Jahrhundert im vergleich zu Mittel- und Westeuropa (Hannover 1974).

${ }^{4}$ M.C. Nelson and J. Rogers, 'Cleaning up the cities: application of the first comprehensive public health law in Sweden', Scandinavian Journal of History, 19 (1994), 21-6; L. Benevolo, The European City (Oxford 1993), 160-188; R. Lennartsson, 'Den mänskliga latrinen. Om Stockholms modernisering och prostitutionens reglementering', Bebyggelsehistorisk tidskrift 44 (2002), 51; B. Gejvall-Seger, 'Stadsplanering och bebyggelseutveckling i Norrköping 1719-1970' in B. Helmfrid and S. Kraft, eds., Norrköpings historia VI. Tiden 1914-1970 (Stockholm 1976), 57-69; Kongl. Maj:ts nådiga Byggnadsstadga för rikets städer, 8 May 1874, SFS, 1874, No. 25; Kongl. Maj:ts nådiga helsowårdsstadga för riket, 25 September 1874, SFS, 1874, No. 68. Central aspects of modern town planning were also inherited from French Enlightenment architecture: R.A. Etlin, Symbolic Space: French Enlightenment Architecture and Its Legacy (Chicago 1994), 1-47. 
Table 1. Population growth as an indicator of urbanization in five Swedish cities, 1850-1910, related to the index 100 in 1850.

\begin{tabular}{|l|r|r|r|r|r|r|r|}
\hline & 1850 & 1860 & 1870 & 1880 & 1890 & 1900 & 1910 \\
\hline Stockholm & 100 & 121 & 146 & 181 & 264 & 323 & 368 \\
\hline Göteborg & 100 & 142 & 216 & 293 & 401 & 500 & 643 \\
\hline Malmö & 100 & 145 & 196 & 291 & 370 & 465 & 637 \\
\hline Norrköping & 100 & 118 & 141 & 158 & 194 & 242 & 274 \\
\hline Linköping & 100 & 117 & 138 & 167 & 241 & 278 & 346 \\
\hline
\end{tabular}

Source: Historisk statistik för Sverige. Del 1. Befolkning 1720-1967 (Stockholm 1969), 61-5.

Simultaneously an urban working class formed when people migrated into, or rather to the outskirts of, larger Swedish industrial cities such as Stockholm, Malmö and Norrköping. New working-class suburbs were the results of city growth and industrialization, and with them came questions of whether or not their inhabitants should enjoy the same technological amenities as people in the city, for instance, water supply, sewerage and other technologies used to improve the urban environment. City governments were uncertain about whether to include these new areas and their inhabitants in the urban space. ${ }^{5}$

These working-class suburbs, or shanty towns (kåkstäder) as they were often called, developed neither from previous urban nor rural structures. Thus they represented something entirely new in late nineteenth century Sweden. Surprisingly little has been written about them and their relationship to the cities, particularly as far as academic studies are concerned. ${ }^{6}$

\footnotetext{
${ }^{5}$ H. Meller, European Cities 1890-1930s: History, Culture and the Built Environment (Chichester 2001), 2-3; Hallström, Constructing a Pipe-Bound City, 13-38, 168-228; A.-M. Thagaard, Backarna. Liv och historia i en förstad (Malmö 1992), 53-108.

${ }^{6}$ I. Johansson, Stor-Stockholms bebyggelsehistoria. Markpolitik, planering och byggande under sju sekler (Hedemora 1991), 236-7. My own studies of the academic literature on working-class suburbs in Sweden confirm the view of Johansson; virtually nothing has been written even since 1991 (Johansson, Stor-Stockholms bebyggelsehistoria and Hallström Constructing a Pipe-Bound City are exceptions, however).
} 
The aim of this article is to study how the Swedish cities Linköping and Norrköping treated new working-class suburbs just outside their planned areas or administrative borders during the period from 1860 to 1890 . Attitudes to the suburbs were expressed in discussions related to piped water supply and sewerage, especially the extension of water. Primary sources about these two cities will also be compared with secondary material concerning a wider Swedish urban context.

Underlying the argument of the article is the assumption that space, which is sometimes seen as something neutral outside the social context, is in fact an implement of social control, and Henri Lefebvre has coined the term 'social space' to denote this. David Harvey argues in line with Lefebvre that 'spatial practices' - that is, appropriation, production, control or representation of space - are inextricably linked to social relations in the city. In modern Western society these spatial practices were imbued with class meanings. ${ }^{7}$ The spaces members of social groups inhabit and the technologies they spatially extend therefore tell us something about social relations in the city.

\section{The Cities of Norrköping and Linköping, Sweden}

The cities of Norrköping and Linköping were very small compared to the larger and the midsized cities on the Continent and in Great Britain (see Table 2 and 3). Nonetheless they were

\footnotetext{
${ }^{7}$ H. Lefebvre, The Production of Space (Oxford 1991), 401-23; D. Harvey, The Condition of Postmodernity: An Enquiry into the Origins of Cultural Change (Cambridge 1990), 201-25. Cf. S. Gunn, 'The spatial turn: changing histories of space and place' in S. Gunn and R. J. Morris, eds., Identities in Space: Contested Terrains in the Western City Since 1850 (Aldershot 2001) and E.W. Soja, 'Reassertions: towards a spatialized ontology' in J. Agnew, D.N. Livingstone and A. Rogers, eds., Human Geography: An Essential Anthology (Oxford 1996), 623$5,633-5$
} 
considered to be cities administratively, financially and culturally, and were both being rather urbanized during the period (see Table 1$)^{8}$

Table 2. Population in Linköping and Norrköping 1860-1920

\begin{tabular}{lrrrrrrr}
\hline & 1860 & 1870 & 1880 & 1890 & 1900 & 1910 & 1920 \\
\hline Linköping & 6,138 & 7,257 & 8,752 & 12,649 & 14,552 & 18,149 & 26,920 \\
& & & & & & & \\
Norrköping & 19,956 & 23,850 & 26,735 & 32,826 & 41,008 & 46,393 & 58,098 \\
\hline
\end{tabular}

Source: Historisk statistik för Sverige. Del 1. Befolkning 1720-1967 (Stockholm 1969), 61-5.

Table 3. Population in some large and mid-sized European cities in 1850, 1900 and 1950

\begin{tabular}{llll} 
& 1850 & 1900 & 1950 \\
\hline London & $2,320,000$ & $6,480,000$ & $8,860,000$ \\
Paris & $1,314,000$ & $3,330,000$ & $5,900,000$ \\
Liverpool & 422,000 & 940,000 & $1,260,000$ \\
Stockholm & 93,000 & 300,000 & 744,000 \\
Christiania/ Oslo & 30,000 & 225,000 & 430,000 \\
Helsinki & 20,000 & 80,000 & 370,000
\end{tabular}

Source: P.M. Hohenberg and L.H. Lees, The Making of Urban Europe 1000-1994 (Cambridge 1995), 11, 227; H. Nygård, 'Avfallet i det urbana rummet: om kodifieringen av renhållningstraditioner och stadsrummets sanitära förutsättningar', Bebyggelsehistorisk tidskrift 44 (2002), 39; M. Bell and M. Hietala, Helsinki, the Innovative City: Historical Perspectives (Helsinki 2002), 433; T.A. Johansen, Under byens gater. Oslos vann- og avlopshistorie (Oslo 2001), 15, 188; Historisk statistik för Sverige. Del 1. Befolkning 1720-1967 (Stockholm 1969), 61-5.

\footnotetext{
${ }^{8}$ Swedish cities were defined as such primarily on administrative grounds, not on population. Charters had been issued since long and the towns served an urban function, which was confirmed in the new urban reform of 1862. This meant that market places and new urban areas that were not designated cities $-k \ddot{o p} p i n g$ and municipality (municipalsamhälle) - could in some cases be larger as regards population: J.-O. Drangert, M.C. Nelson and H. Nilsson, 'Why did they become pipe-bound cities? Early water and sewerage alternatives in Swedish cities', Public Works Management \& Policy 6, 3 (2002), 173.
} 
Norrköping is situated on the river Motala Ström in the eastern part of Östergötland County in southeastern Sweden, just before the river reaches the bay Bråviken and the Baltic Sea (see Figure 1). Louis de Geer made Norrköping the centre of his manufacturing empire in the early seventeenth century, when he established the first paper and brass mills there, followed a few years later by the textile manufactory Drags. By the mid-nineteenth century Norrköping was dominated by several smaller woollen manufactories. ${ }^{9}$ In the 1840 s and 1850 s the popularity of finer cloth declined, while the demand among workers and farmers for cheap fabrics increased. The textile manufacturers consequently had to mechanize production to be able to mass produce this cloth. Mechanization meant significant investments for the small woollen manufacturers, and some instead invested in the cotton industry. The remaining woollen companies either disappeared or merged with others into larger modern joint-stock companies in the 1860 s and 1870 s. The dominance of the woollen industry was not only great in the city - in 1870, 52 percent of the city's industrial workers were employed there; Norrköping's woollen industry was foremost in the country. In the 1860s Norrköping was one of the most successful industrial cities in Sweden, second only to the capital Stockholm. ${ }^{10}$

\footnotetext{
${ }^{9}$ B. Horgby, Surbullestan (Stockholm 1989), 38; T. Söderberg, 'Norrköpings ekonomiska och sociala historia 1719-1870' in B. Helmfrid and S. Kraft, eds., Norrköpings historia IV: Tiden 1719-1870 (Stockholm 1968), $17-$ 73; C. Hugerth, Holmen: A Swedish Industrial History (Norrköping 1996), 2; L. Schön, En modern svensk ekonomisk historia. Tillväxt och omvandling under två sekel (Stockholm 2000), 97-8.

${ }^{10}$ J. Hallström, 'Den sundaste staden i Europa? Renhållningsfrågan i Norrköping 1885-1895' in P. Eliasson and

E. Lisberg Jensen, eds., Naturens nytta. Från Linné till det moderna samhället (Lund 2000), 189; Horgby, Surbullestan, 38-41; Schön, En modern svensk ekonomisk historia, 98-100; J. Svensson, S. Godlund and K. Godlund, 'Norrköpings ekonomiska och sociala historia 1870-1914' in B. Helmfrid and S. Kraft, eds., Norrköpings historia V. Tiden 1870-1914 (Stockholm 1972), 2, 10-11, 78-80, 95-7, 180-1, 239-245; K. Nyberg, 'Brittisk teknik, svensk överföring och finländskt mottagande? Textilindustrin i Sverige och Finland 1809-1870. Exemplet ylleindustrin', Historisk tidskrift 120, 4 (2000), 623-4.
} 


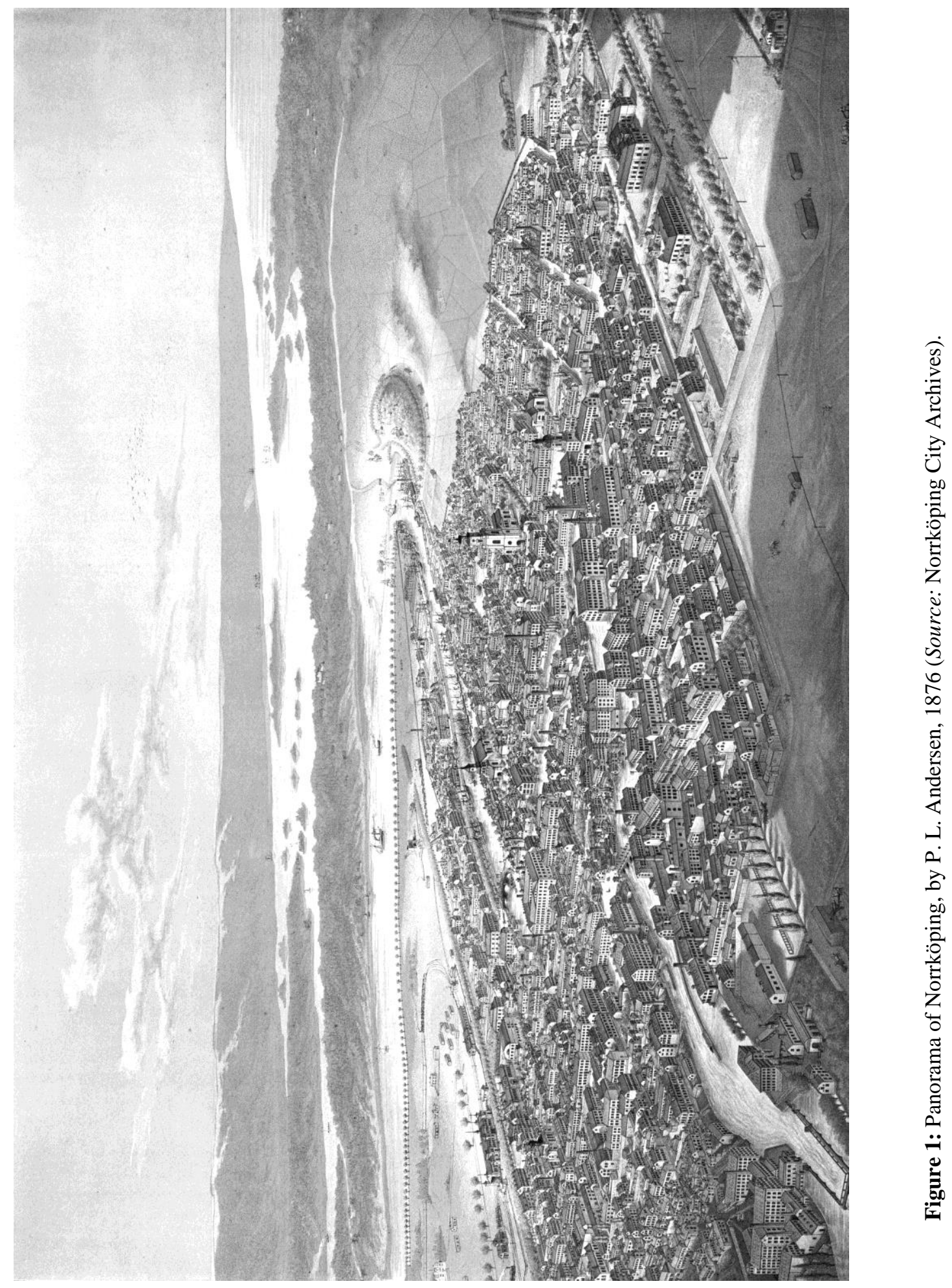

Linköping lies on the river Stångån just south of Lake Roxen, around 40 kilometres southwest of Norrköping (see Figure 2). Linköping had been an ecclesiastical and educational centre for centuries, and the seat of the County Government since 1634. It was also the agricultural centre of the surrounding fertile plain, the so-called Östgötaslätten, and some of 
the landed gentry owned houses in the city. Since the Middle Ages Linköping had been a socalled uppstad, which meant that the town's merchants were not allowed to trade with the international market directly, but had to go through the nearest Swedish stapelstad, an international port. The closest one was Norrköping, although in 1874 Linköping also received the right to direct international trade. Prior to that date local trade, handicraft, and small businesses thrived thanks to the close proximity to the farming district. Linköping was also a garrison city with a military base outside the city limits, at Malmslätt. ${ }^{11}$

In contrast to Norrköping, Linköping was no industrial city, at least not if we look at the economic activities within the actual city boundary. If the industries on the other side of the river in the St. Lars rural district (landskommun) are also taken into account, the city stands out as a little more industrialized, but it was still far behind Norrköping. The few industries within the city were mostly situated along the river. Asklund's tobacco factory, which was the largest one, had around 50 workers in the 1860s. On the eastern bank of Stångån, in Ladugårdsbacke, lay L. T. Brogren's brewery, as well as mills, textile factories, and a distillery at Tannefors and Nykvarn. ${ }^{12}$

\footnotetext{
${ }^{11}$ S. Andersson, 'Politik och demokrati' in H. Nilsson, ed., Norrköpings historia. 1900-talet (Linköping 2000), 298-9; G. Bagge, Ungdomsminnen från östgötabygder (Linköping 1922), 50-60; S. Förhammar,

'Garnisonsstaden' in S. Hellström, ed., Linköpings historia 5. Tiden 1910-1970 (Linköping 1981), 287; S.

Hellström, 'Befolkning och social struktur' in S. Hellström, ed., Linköpings historia 4. Tiden 1863-1910

(Linköping 1978), 11-13; R. Marks von Würtemberg, Min barndoms Linköping (Linköping 1955), 81-100; D.

Torbrand, 'Kommunikationernas förändring' in S. Hellström, ed., Linköpings historia 4. Tiden 1863-1910

(Linköping 1978), 92-4.

${ }^{12}$ P. Almroth and S. Kolsgård, 'Näringsliv' in S. Hellström, ed., Linköpings historia 4. Tiden 1863-1910

(Linköping 1978), 111-43; Hellström, 'Befolkning och social struktur', 11-13.
} 


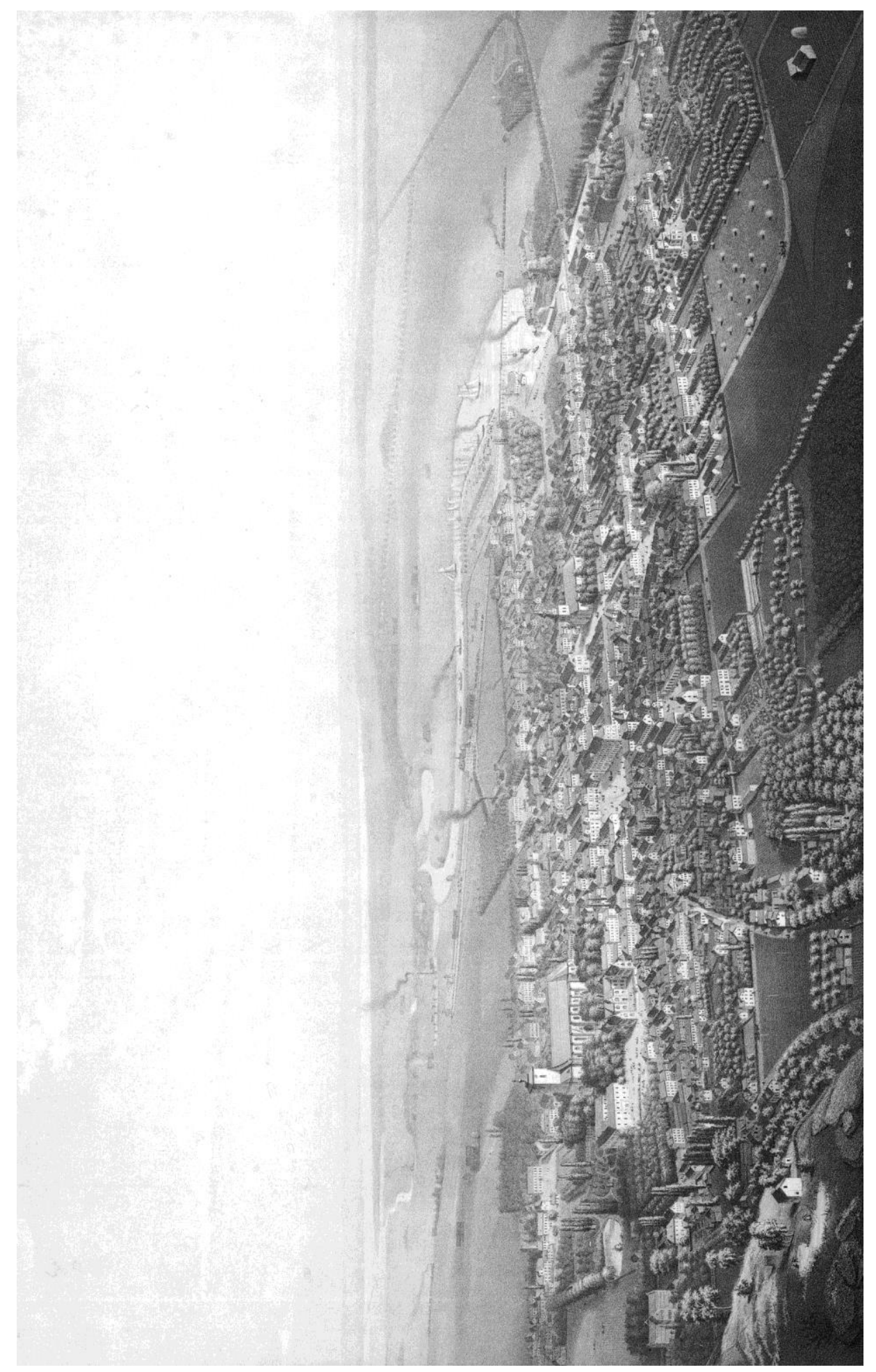

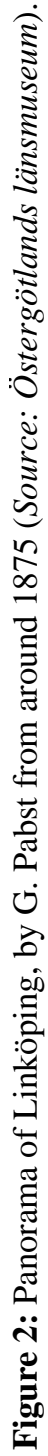

\section{The Suburbs of Norrköping and Linköping}

A consequence of industrialization and urbanization in Sweden was the appearance of suburban shanty towns. Housing shortage, with accompanying high rents and increased land 
prices, drove the working class in particular outside the city's planned area or its administrative border, ${ }^{13}$ where building was not restricted by national urban building, fireprotection and health laws and was therefore less expensive. ${ }^{14}$

Norrköping's northern suburb, which belonged to the Östra Eneby rural district north of the city, was seen by many as a shanty town. The area was marshy and not suitable for farming, so the property owners divided it into building sites, which were then sold for lower prices than in the city. The suburb had its origins around 1860 and at that time had about 60 inhabitants. The area was situated along the main Eastern railway line, which was under construction from 1863 to 1866 , but the population did not grow much during the 1860 s. ${ }^{15}$ The transformation into a suburb crowded enough to be regarded as a problem area by local and regional authorities occurred during the economic boom of the 1870s, when population increased incredibly rapidly. ${ }^{16}$ The inhabitants were mostly workers and poor people.

The housing and sanitary conditions in Swedish industrial towns at this time were generally poor, but in Norrköping these conditions were probably even worse, particularly in

\footnotetext{
13 The city's planned area, as it was marked out by the city plan, constituted the actual city in administrative and judicial terms, and the national urban general regulations, building codes, health and fire laws were only applicable there. Areas outside the planned area were considered to be the countryside, despite the fact that they sometimes lay within the city border. Swedish cities thus often included land that was administered by the city but was not formally urban: Y. Larsson, Inkorporeringsproblemet. Stadsområdets förändringar med särskild hänsyn till svensk förvaltningspraxis, del I \& II (Stockholm 1913), 373-6.

${ }^{14}$ Larsson, Inkorporeringsproblemet, 13, 105.

${ }^{15}$ M. Arvidsson, 'Från förstad till stadsdel. En studie av inkorporeringen av Norra förstaden med Norrköpings stad 1886-1916', (unpublished Linköping University Masters thesis, 1995), 10-11; R. Myrdal, Styrelse, förvaltning, politik 1863-1919, Norrköpings historia 11 (Uppsala 1972), 301-3, 396; Gejvall-Seger, 'Stadsplanering och bebyggelseutveckling', 81, 90.

${ }^{16}$ Horgby, Surbullestan, 31-3; Larsson, Inkorporeringsproblemet, 105; Arvidsson, 'Från förstad till stadsdel', 11.
} 
its suburbs. ${ }^{17}$ In the northern suburb houses were often crowded and built of poor materials; even stables were sometimes turned into apartments. ${ }^{18}$ Sanitary measures of any kind were lacking, water supply was rudimentary, and the suburb sewers ended in open trenches. These conditions differed within the northern suburb, however; there were better and worse places to live. ${ }^{19}$

In Linköping the area east of the river Stångån was not under the city's jurisdiction. It belonged to the St. Lars rural district, which surrounded the city, and one of Linköping's several suburbs, Ladugårdsbacke, was situated there. Like Norrköping's northern suburb, it was considered to be a shanty town; the area was partly marshy and sanitation was very poor. It was also a working-class area, in close proximity to the industrial districts Nykvarn and Tannefors on the river. ${ }^{20}$

\section{City versus Suburb - the Extension of Water}

Modern water supply and sewer systems were constructed in Norrköping between 1872 and 1875. According to Norrköping water delivery practice, pipes outside the planned area had to

\footnotetext{
${ }^{17}$ Svensson, Godlund and Godlund, 'Norrköpings ekonomiska och sociala historia', 259-67.

${ }^{18}$ Horgby, Surbullestan, 31-3.

${ }^{19}$ Norrköping City Archives (NSA), Norrköping City Council Archives, supplement No. 15 1893; Svensson, Godlund and Godlund, 'Norrköpings ekonomiska och sociala historia', 267. The northern suburb consisted of three distinct areas. Marielund was the western part, Fredriksdal the eastern part, and Sandby the northern part (see Figure 3).

${ }^{20}$ Myrdal, Styrelse, förvaltning, politik, 283; Almroth and Kolsgård, 'Näringsliv', 111-24; D. Torbrand, 'Stadsplanering' in S. Hellström, ed., Linköpings historia 4. Tiden 1863-1910 (Linköping 1978), 25-32; H. Nilsson, Mot bättre hälsa. Dödlighet och hälsoarbete i Linköping 1860-1894 (Linköping 1994), 140-1. Ladugårdsbacke consisted of several smaller areas such as Ladugårdsbacke, Ladugårdsgärde and Tomteboda, but the former will hereafter be used as a common name for the whole area (it is the most frequently used in the literature).
} 
be paid for by the building owners themselves, and this meant that few in the northern suburb could afford a connection to the city's piped water supply. A company just north of the city border, the engineering workshop Norrköpings Mekaniska Verkstad, was granted the right to distribute water to the inhabitants of the eastern part of the suburb, Fredriksdal, particularly to those living in close proximity to its premises. In this way, the City Council could attend to the needs of this poor suburban district and still make some money, since the company both paid for the infrastructure and the water..$^{21}$

In the 1880 s, the number of inhabitants in the northern suburb grew quickly, reaching the level of some 3,000 inhabitants. $^{22}$ In 1885 , the suburb became a municipality (municipalsamhälle). It was really a part of the rural district Östra Eneby, adjacent to the city of Norrköping, but by being designated a municipality the suburb came under the national urban laws while remaining a part of the rural district administratively, judicially and ecclesiastically. ${ }^{23}$ For instance, the building of houses and privies hereby came under the urban building codes, although it is difficult to say how much effect the regulations had in practice. $^{24}$

\footnotetext{
${ }^{21}$ NSA, Norrköping City Council Archives, AI a:12 and AI a:13, minutes 1874-11-26 section 6 and 1875-09-09 section 6; Svensson, Godlund and Godlund, 'Norrköpings ekonomiska och sociala historia', 178-9; Hallström, Constructing a Pipe-Bound City, 170-203, 336-7. Although the sources are not clear on this point, it seems likely that the engineering workshop in its turn charged the inhabitants for the water.

${ }^{22}$ Arvidsson, 'Från förstad till stadsdel', 11, 20.

${ }^{23}$ Arvidsson, 'Från förstad till stadsdel', 12; L. Nilsson, Den urbana transitionen. Tätorterna i svensk samhällsomvandling 1800-1980 (Stockholm 1989), 53-6; Larsson, Inkorporeringsproblemet, 107; Gejvall-Seger, 'Stadsplanering och bebyggelseutveckling', 82; NSA, Norrköping City Council Archives, supplement No. 43 1893 and No. 11894.

24 'Byggnadsordning för Norrköpings Norra Förstäders område', Kongl. Maj:ts Befallningshafvandes $i$ Östergötlands län allmänna kungörelser, Serien B, No. 431885 (Norrköping 1922).
} 
In the middle of the 1880s, the inhabitants of the northern suburb began demanding help from the city with necessary infrastructure and services. Both private and common water taps, for instance, were too few. In 1886, a committee from Fredriksdal wrote to Norrköping Waterworks Board ${ }^{25}$ to ask if a water pipe could be extended from the engineering workshop along one of the streets. The Waterworks Board was not in favour of any new extensions of the water supply. Water consumption was increasing and the waterworks' pumps were already at maximum capacity, so expansion outside the planned area could not be allowed. If the suburb was granted the extension it would also be very difficult to deny other suburbs water infrastructure. Furthermore, the board was of the opinion that more water would increase rather than decrease sanitary problems, since drainage was so poor in the suburb. ${ }^{26}$

Not only was the Waterworks Board divided in this question, but so was the City Council, which became apparent at a meeting in late 1886 . There was a long discussion and there were several proposals, some of which were put to the vote. A detailed account of the discussion, which was published in the local newspaper Norrköpings Tidningar the day after the meeting, reveals deep disagreement among the members of the Norrköping City Council in this question. $^{27}$

The proponents of the water extension started out by contradicting the Waterworks Board's technical argument, namely that the pumps were running at their maximum rate. Fredrik Blombergh was of the opinion that the pumps were capable of working either a little faster or

\footnotetext{
${ }^{25}$ The Waterworks Board was the city's administrative unit for the water and sewer systems. It was placed under the City Council, but was also financially responsible to the city's Financial Department.

${ }^{26}$ NSA, Norrköping City Council Archives, minutes 1886-10-21 section 4; Norrköping Waterworks Board Archives, AI:2, minutes 1886-09-22 section 2 and 1886-11-06 section 3.

${ }^{27}$ NSA, Norrköping City Council Archives, minutes 1886-11-18 section 16; Norrköping Waterworks Board Archives, AI:2, minutes 1887-03-19 section 3; Account of the City Council meeting 1886-11-18, Norrköpings tidningar (NT) 1886-11-19.
} 
a little longer per day without actually straining them, and thereby both the city and the northern suburb could be supplied with water. The opponents, who basically supported the Waterworks Board, did not share this optimistic view of the capacity of the city's water supply, and they were afraid that the city itself soon would lack water. ${ }^{28}$

Issues of quality, quantity, and availability of the water were also debated, and the assumption was that these aspects influenced the sanitary conditions in the suburb one way or another. The proponents thought that the northern suburb needed not only a pure and ample supply of water, which was necessary from a sanitary point of view, but also a readily available supply. That is, pipes had to be extended, if not to each household, at least in close proximity to them. The suburb had been under the national building code since 1885 , but most buildings were still not in any condition to have service pipes installed. Extended pipes were important also for convenience, according to the proponents. ${ }^{29}$

The opponents, on the other hand, regarded the water tap at the premises of the engineering workshop as quite enough, since it delivered pure city water. An extension would certainly mean convenience for the people in the area, but was not at all necessary for sanitary purposes. The single water standpipe was good enough; if they wanted more water they could dig their own wells, which would also be cheaper for them. ${ }^{30}$

Another sanitary aspect was the fear of epidemics, especially cholera. This fear was rather widespread among both groups, particularly since, in their view, it was very likely that an epidemic would spread to Norrköping as well: '[Epidemics] hang, . . . because of the suburb,

\footnotetext{
${ }^{28} N T$ 1886-11-19.

${ }^{29}$ NT 1886-11-19; 'Byggnadsordning för Norrköpings Norra Förstäders område', Kongl. Maj:ts Befallningshafvandes i Östergötlands län allmänna kungörelser, Serien B, No. 431885 (Norrköping 1922).

${ }^{30}$ NT 1886-11-19.
} 
like a sword of Damocles over the city of Norrköping,' as Axel Molin said. ${ }^{31}$ The proponents were of the opinion that it would then be an advantage for the city itself if the northern suburb had piped water - but they had to arrange better sewerage first - while the opponents argued that the extension of water would in such a situation only mean an even bigger threat to the city because of the poor drainage in the suburb. ${ }^{32}$

In connection with this, humanitarian arguments were put forward by the proponents. Since so many inhabitants of the northern suburb worked in Norrköping, it was the duty of the city to help: 'It is the duty and obligation of the city to extend a helping hand to the inhabitants of the suburb,' said Fredrik Blombergh. Edward Rodhe added that 'the inhabitants of Norrköping have a moral obligation toward the northern suburb. ${ }^{33}$ The opponents, on the other hand, wondered where to draw the line if other surrounding areas, notably working-class areas, demanded the right to water on the same grounds. ${ }^{34}$

At this time, it was known by the City Council that the northern suburb intended to ask to be incorporated in the city of Norrköping, but both groups favoured the separation between the suburb and the city in the long run, even though neither explained how this was to be realized. For the proponents, helping the suburb with the water extension was a way of making the future separation smoother. The opponents feared that expanding the water system would either draw the suburb and the city closer to each other - not only water but also other

\footnotetext{
${ }^{31} N T$ 1886-11-19. Epidemics probably lived in the memories of the city's inhabitants as the city had been hard hit by cholera in 1853 and 1866: E. Gullberg, 'Norrköpings kommunalstyrelse 1719-1862' in B. Helmfrid and S. Kraft, eds., Norrköpings historia IV. Tiden 1719-1870 (Stockholm 1968), 114-5; Svensson, Godlund and Godlund, 'Norrköpings ekonomiska och sociala historia', 268.

${ }^{32}$ NT 1886-11-19; ’Byggnadsordning för Norrköpings Norra Förstäders område', Kongl. Maj:ts Befallningshafvandes $i$ Östergötlands län allmänna kungörelser, Serien B, No. 431885 (Norrköping 1922). ${ }^{33} N T$ 1886-11-19.

${ }^{34} N T$ 1886-11-19.
} 
public services would then be demanded - or make the suburb grow even faster. Both these developments would lead to a more difficult process of separation. ${ }^{35}$

Discussing otherwise humanitarian issues, both proponents and opponents of the water extension saw the northern suburb as a growth ${ }^{36}$ : 'As it is now, the northern suburb is undeniably a serious growth on the city of Norrköping; sooner or later it will be necessary to operate on it, and this operation will not be easy,' said Fredrik Blombergh, one of the proponents. ${ }^{37}$ The suburb was also referred to as weed, which should not be watered in order to avoid its spreading. ${ }^{38}$ As a matter of fact, the suburb itself also noted that it had become a 'sewer for . . the worst and basest elements' of the city. ${ }^{39}$

The content of this 'sewer' was mostly workers and poor people, but also criminal 'elements.' At times, it seems to have been the city's tacit policy to rent dwellings for its poor people in the northern suburb, so that the rural district Östra Eneby eventually was obliged to support them. ${ }^{40}$ Other sources also show that the city's workers sometimes felt driven out of the city. This can be seen in a letter to the editor of Norrköpings Tidningar from a worker who complained about the building of new worker's dwellings on a building lot at the outskirts of the city: '[I]s the spot most suitable for worker's dwellings in order to separate the worker from the city as much as possible? So it seems ... since everyone knows that there are other spacious, healthy, and good building sites in the city itself . ... 41

\footnotetext{
${ }^{35}$ NT 1886-11-19.

${ }^{36}$ In Swedish utväxt, implying a tumour, something sick or unnatural which has grown out of something else.

${ }^{37} N T$ 1886-11-19.

${ }^{38} N T$ 1886-11-19.

${ }^{39}$ Larsson, Inkorporeringsproblemet, 555.

${ }^{40}$ Horgby, Surbullestan, 32. The costs for poor relief should be paid for by the administrative authority of the area in which the poor lived, in this case Östra Eneby: Larsson, Inkorporeringsproblemet, 106.

${ }^{41} N T$ 1872-05-28.
} 
Eventually, there was a slight majority in favour of a proposal that on the whole resembled the suburb committee's original one, but with some additional requirements. The water pipe was to be about 200 metres long, and it would supply those living adjacent to it with city water for a fee (see Figure 3). The pipe was to be supervised by Norrköping's waterworks engineer, B. L. Hellström, and the committee had to see to it that proper drainage was arranged. The proponents of the extension of water were therefore successful in the end. In that sense one can say that a humanitarian strand in the Norrköping City Council was victorious. In the long run, however, infrastructural improvements in the northern suburb were not prioritized by the council, since no further extensions occurred until 1909 and $1910 .{ }^{42}$

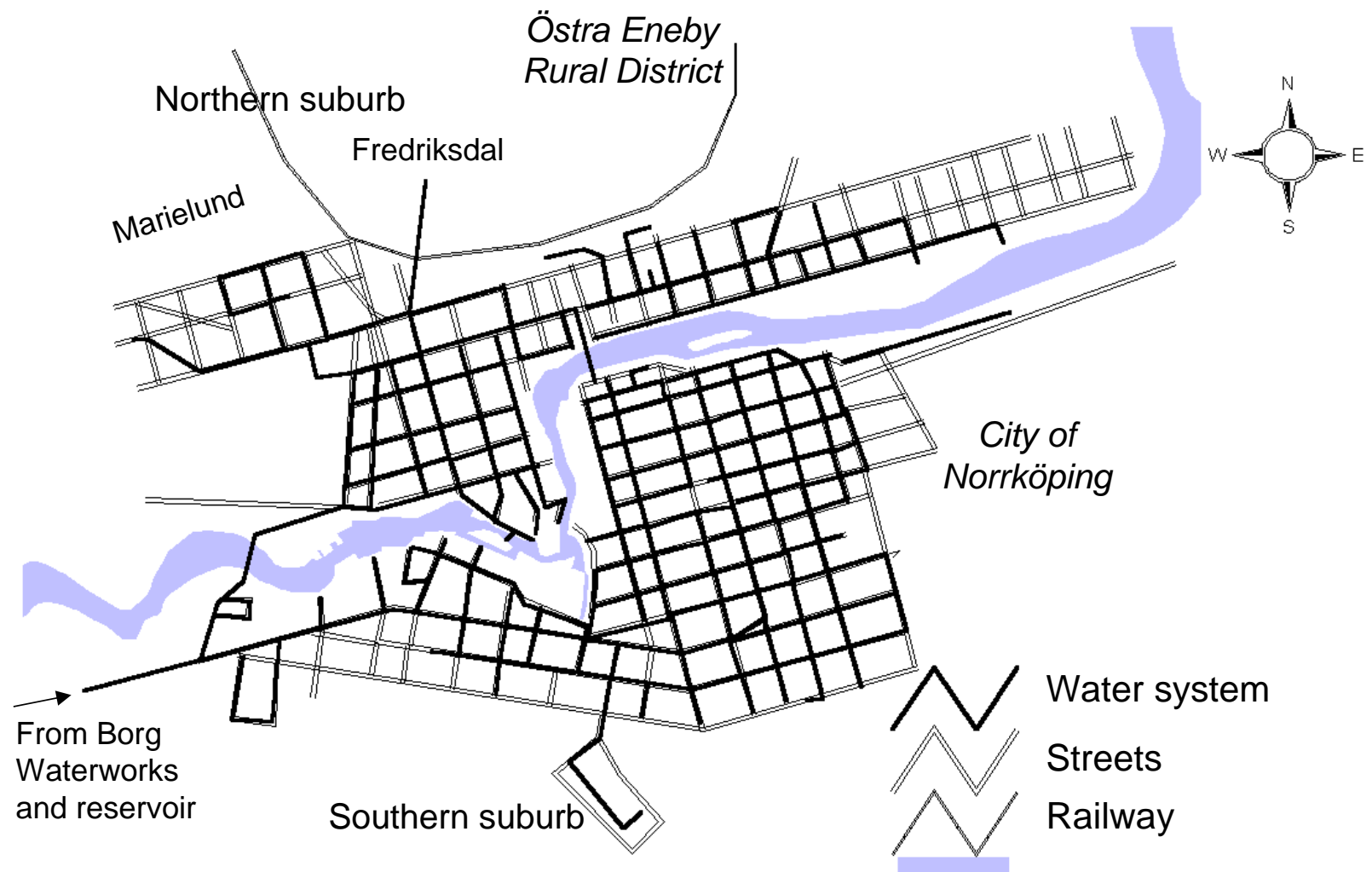

River Motala ström

Figure 3: The Norrköping water system in 1896. The network of streets roughly corresponds to the planned area of the city of Norrköping (Sources: T. Schmid and J. Hallström, 'The pipe-bound city in time and space: applying GIS to the historical development of the city and its water and sewer systems - Linköping and Norrköping, Sweden, ca. 1860-1915',

\footnotetext{
${ }^{42}$ Hallström, Constructing a Pipe-Bound City, 63-103, 170-6, 184-5, 203.
} 
International Water History Association $2^{\text {nd }}$ Conference, 10-12 August 2001, at Bergen, Norway; Hallström, Constructing a Pipe-Bound City, 197).

In 1874 to 1876 a modern waterworks and a sewer system were built in Linköping. The first suburb to catch the attention of the city of Linköping as regards the extension of water was Ladugårdsbacke in 1881. The brewery owner Ludvig Theodor Brogren and 16 home owners in Ladugårdsbacke wanted to connect to the city's water supply, and expected to be given water on the same conditions as people in the city. The Linköping Water Company, which owned and administered the water supply with the city as a 20 percent joint owner, acted quickly. Within two days their engineer C. J. Stenmark had drawn up a plan and made an estimate of the costs. It showed that the expected income from water fees would by far surpass 10 percent of the costs of construction, according to the so-called ' 10 percent rule.' Brogren's brewery was a large consumer and alone would pay 400 Swedish kronor a year. ${ }^{44}$

With the influential Brogren spearheading this matter, one would think that it should have been settled quite easily, especially since he was a member of the City Council as well as a shareholder in the Water Company. But the city was strongly opposed to extending a water pipe to Ladugårdsbacke. The city's Drafting Committee ${ }^{45}$ first of all maintained that this area lay outside the city border. Secondly, the waterworks pumping station was already overstrained, and an extension would hasten the installation of a new pump at Tannefors

\footnotetext{
${ }^{43}$ This rule was set up by the Linköping Water Company in 1875 to ensure that every new extension had paid within 10 years: Hallström, Constructing a Pipe-Bound City, 143. This was a common way of financing the extension of technological systems to new areas in other Swedish cities as well: Larsson, Inkorporeringsproblemet, 354 .

${ }^{44}$ Linköping City Archives (LiSA), Linköping City Council Archives, AI:19, minutes 1881-06-22 section 73; Linköping Water Company Archives, AI:1, minutes of the shareholders' meeting 1881-05-31 section 8; Account of the City Council meetings 1881-06-22 and 1881-07-26, Östgöta Correspondenten (ÖC) 1881-06-25 and 1881-07-28.

${ }^{45}$ The Drafting Committee was a part of the City Council that prepared important political questions.
} 
waterworks. The view of the committee thus differed from that of the Water Company, which should have had the best knowledge of the capacity of the waterworks. Thirdly, the committee feared that other areas around the city would ask for water pipes if this case was approved. ${ }^{46}$

During this City Council meeting, Brogren argued for his and the suburb's request. There had been no objections to their proposal among the shareholders of the Water Company, and the pipe would be of great importance from a sanitary point of view and in case of a fire. ${ }^{47}$ Nils Östling, lecturer in Latin and Greek and a member of the Swedish Parliament, expanded on his view of the subject. He believed that the proposed extension would not pay due to lack of any guarantees that there would be continued and extended water consumption in Ladugårdsbacke. Besides, the contract with the Water Company did not allow for extensions outside the city, in his opinion. ${ }^{48} \mathrm{He}$ also said that the advantages of piped water in case of epidemics or fire would not be so much greater, due to the existing easy access to an ample supply of river water. This latter argument should not have convinced either people in the suburb or in the city, on the other side of that same river, as there was growing concern about the deteriorating quality of the river water. ${ }^{49}$

\footnotetext{
${ }^{46}$ LiSA, Linköping City Council Archives, AI:19, minutes 1881-07-26 section 81; Linköping Water Company Archives, AI:1, minutes of the shareholders' meeting 1882-05-30 section 7; Account of the City Council meeting 1881-07-26, ÖC 1881-07-28.

${ }^{47} \ddot{O C} 1881-07-28$. There can be no doubt that Brogren and the Water Company also had economic interests in the extension.

${ }^{48}$ This was a dubious statement. The contract between the city and the Water Company allowed for extensions outside the city's planned area, provided the case in question was submitted to the City Council, but it said nothing about expansion outside the city boundary: Hallström, Constructing a Pipe-Bound City, 204, 211-17. ${ }^{49} \ddot{O} C 1881-07-28$.
} 
The ensuing City Council decision on this matter was not unanimous, but the proposal to extend a water pipe to Ladugårdsbacke was rejected..$^{50}$ Ladugårdsbacke was denied the city's piped water until 1921, in spite of its incorporation into the city as early as 1911.

\section{Water Distribution to Workers' Suburbs in Other Swedish Cities}

Little has been written about working-class suburbs in other Swedish cities during this period in terms of the academic literature, and this will be complemented with other source material - amateur ethnological and historical studies, novels, pamphlets - to see if the situation in Norrköping and Linköping was unique or part of a larger picture. In-depth studies of each city below need to be carried out in the future, but the outline will do as a context to the development in the two case cities.

Outside Stockholm, the Swedish capital, there emerged several working-class suburbs in the late nineteenth century, many of which resembled the northern suburb and Ladugårdsbacke. Two examples will be examined, Årstadal to the south and Hagalund north of the city. Årstadal was an area near the bay Årstaviken and the railroad, and it was partly very marshy. Count Erik Sparre and the engineer Charles J. Smith started selling building lots there in the mid-1870s, on very unfavourable conditions. Owing to the housing shortage in the city, however, by 1882 a number of wooden houses and around 1,000 mostly working-class inhabitants existed in Årstadal. ${ }^{51}$

There was no building code for the area and sanitary conditions were very poor - the water supply consisted of poor wells, drains and sewers were lacking, and privies were overflowing - which resulted in several severe epidemics emanating from the suburb. Neither Sparre, the Brännkyrka district nor the city of Stockholm would have anything to do with the 'alien

\footnotetext{
${ }^{50}$ LiSA, Linköping City Council Archives, AI:19, minutes 1881-07-26 section 81.

${ }^{51}$ Johansson, Stor-Stockholms bebyggelsehistoria, 237-42.
} 
element' that the suburb constituted. Water and sewerage were not extended to Årstadal during the nineteenth century, in spite of the close proximity to the reservoirs of the Stockholm water system. ${ }^{52}$

Hagalund was located closer to the city, had a better topography, and the overall conditions were also more favourable, although some parts were considered to be slum areas of the worst sort. It had emerged in the same dubious way, and by means of the same person, as Årstadal. In 1890 Charles J. Smith was commissioned by the landowner, Captain Albert Amundson of the Royal Corps of Engineers, to start selling property in Hagalund, and this was done in the same speculative manner as in Årstadal. Soon workers, artisans and poor people began moving to the suburb. After a few years, the municipality made a great financial effort to build a rudimentary sewer system in the suburb, though in the early 1900 s the water supply was still obtained from wells. ${ }^{53}$

The workers' suburbs of Stockholm had a very bad reputation in the city, and the city feared that both epidemics and working-class revolts might start there and hit the city. The suburbs lay in neighbouring rural districts and had emerged as the result of speculative business of wealthy landowners, and the latter were therefore seen as responsible for necessary services. Consequently, the city of Stockholm consistently denied all its suburbs access to the urban water and sewer systems until at least the early twentieth century. ${ }^{54}$

Outside the city of Malmö, in the very south of Sweden, a working-class suburb called Kirseberg began emerging out of a rural district east of the city in the 1860s. During the 1870s it grew very rapidly as a result of the economic boom and the establishment of new factories

\footnotetext{
52 Johansson, Stor-Stockholms bebyggelsehistoria, 237-58; E. Isgård, I vattumannens tecken. Svensk VA-teknik från trärör till kväverening (Örebro 1998).

${ }^{53}$ O. Roth, Hagalund - en lifskraftig förstad. Kort historik rörande detta municipalsamhälles tillkomst, utveckling och uppsving (Stockholm 1905); Johansson, Stor-Stockholms bebyggelsehistoria, 254-8.

${ }^{54}$ Johansson, Stor-Stockholms bebyggelsehistoria, 237-65; Larsson, Inkorporeringsproblemet, 355.
} 
in the city. People in great numbers moved in from the countryside, and since the city itself was short of housing, many migrants settled in Kirseberg outside the city's planned area, where building regulations were lacking and houses could be built rapidly and with inexpensive materials. Even here a landowner knew how to take advantage of the situation. Carl Petter Andersson bought building lots in Kirseberg and sold them at a much higher price, although it was lower than in the city. ${ }^{55}$

Powerful men in Malmö wanted to prevent poor settlers from entering the city. Apart from workers and the poor, Kirseberg in particular was also known to harbour criminal 'elements' and prostitution. The merchant L. Osberg, a representative of the city's poor-relief organization, wanted to exclude workers and artisans by demanding a six-month rent in advance for new tenants. He would only allow orderly workers in the city. His proposal came to naught, but still tells us something about prevalent attitudes toward workers and poor from suburbs like Kirseberg. ${ }^{56}$

Sanitation and drainage in Kirseberg were inadequate, and water was provided by wells. In 1879 Malmö's second waterworks was built in Bulltofta, southeast of Kirseberg, and the water tower was placed right in the suburb. Some newly-built houses were demolished to make way for the large conduit between the waterworks and the water tower, but the suburb inhabitants were not allowed to connect. Not until the early twentieth century were there any connections to the water system from Kirseberg, and it was only in the 1920s that a complete coverage of connections to the Malmö water and sewer systems was achieved. ${ }^{57}$

\footnotetext{
55 Thagaard, Backarna, 53-61.

56 Thagaard, Backarna, 66, 81-4.

${ }^{57}$ Isgård, I vattumannens tecken, 20-1; Thagaard, Backarna, 74, 83-5; A.-M. Thagaard and A.K. Ribbing, Livet på Backarna - att växa upp i en förstad i början på 1900-talet (Malmö 1985), 168-9; G. Olsson, ’The struggle for a cleaner urban environment: water pollution in Malmö 1850-1911', Ambio: A Journal of the Human Environment 30, 4-5 (2001), 290-1. A modern sewer system for the city of Malmö was completed in 1908.
} 


\section{Cities, Working-Class Suburbs and Water Distribution in Perspective}

By Swedish standards Norrköping and Linköping were early in introducing modern water supply and sewerage in the 1870s. As Martin Melosi points out using examples from the USA, investment in a water system has in the modern era often indicated a commitment to city growth. Financiers and administrators of large technological systems such as water and sewerage, which require large initial investments, have therefore tended to favour extensions as a way of financing the whole system, for example, for amortizing loans or paying investors. ${ }^{58}$ In both Linköping and Norrköping the water and sewer systems were expanded a great deal by the Water Company and the Waterworks Board up until the 1890s, but this was always to areas that were deemed financially viable, were considered necessary for future economic or industrial activities or were otherwise uncontroversial. ${ }^{59}$

The working-class suburbs that were emerging around both cities, on the other hand, constituted new problems of legal status, property ownership, topography, sanitation and many other factors different from areas within the city. Since these working-class suburbs were new phenomena in the 1860s and 1870s there were few antecedents to draw inspiration from regarding how to handle the problem of distributing water there. Several other Swedish cities, particularly industrial ones, faced similar problems at this time, but cooperation between cities seems to have begun only after $1900 .{ }^{60}$

\footnotetext{
${ }^{58}$ M.V. Melosi, The Sanitary City: Urban Infrastructure in America from Colonial Times to the Present (Baltimore 2000), 119-21. Cf. A. Kaijser, I fädrens spår. Den svenska infrastrukturens historiska utveckling och framtida utmaningar (Stockholm 1994), 57-63.

${ }^{59}$ Hallström, Constructing a Pipe-Bound City, 168-228. A middle-class Norrköping suburb - the southern suburb - received water and sewerage as early as 1876 and 1877, for example (see Figure 3).

${ }^{60}$ Hallström, Constructing a Pipe-Bound City, 200-1, 336-7.
} 
The working-class suburbs of Norrköping, Linköping and the other Swedish cities in this study share some common characteristics. These areas were located outside the cities' planned areas, and often beyond the administrative borders, where building, fire or public health codes did not apply. The property on which the suburbs were built was not suitable for farming or commercial activities, the result of which was land speculation. Property owners used the housing shortage in the cities to make money on suburban building lots of little value. They did little or nothing to make water or drainage conditions better in these suburbs, so the environment was marshy and unhealthy, and epidemics often originated in the crowded housing areas.

These alarming conditions in close proximity to the cities, and the fact that the suburbs were growing, forced the cities to deal with them. By looking at the evidence from Norrköping and Linköping we can see what attitudes existed to the working-class suburbs, what actors and factors were involved and what the outcome was in terms of the extension of water. A great many arguments were put forward by different actors in both cities, for or against the extension of water to the suburbs, but these need to be analysed as part of a larger picture where many complex factors interacted.

First of all, the geographical location and topography of each suburb played an important part. The fact that the areas were marshy made them not only unsuitable for farming and commercial activities but also for the building of proper houses, which is probably one reason why many cities did not consider growth in this direction. The Norrköping case also shows that the marshy environment and poor drainage made many, but not all, council members oppose a water extension as they feared that this would make the waterlogged conditions worse. Ladugårdsbacke was also geographically disadvantaged in that it was both partly marshy and situated on the other side of the river Stångån (see Figure 4). 


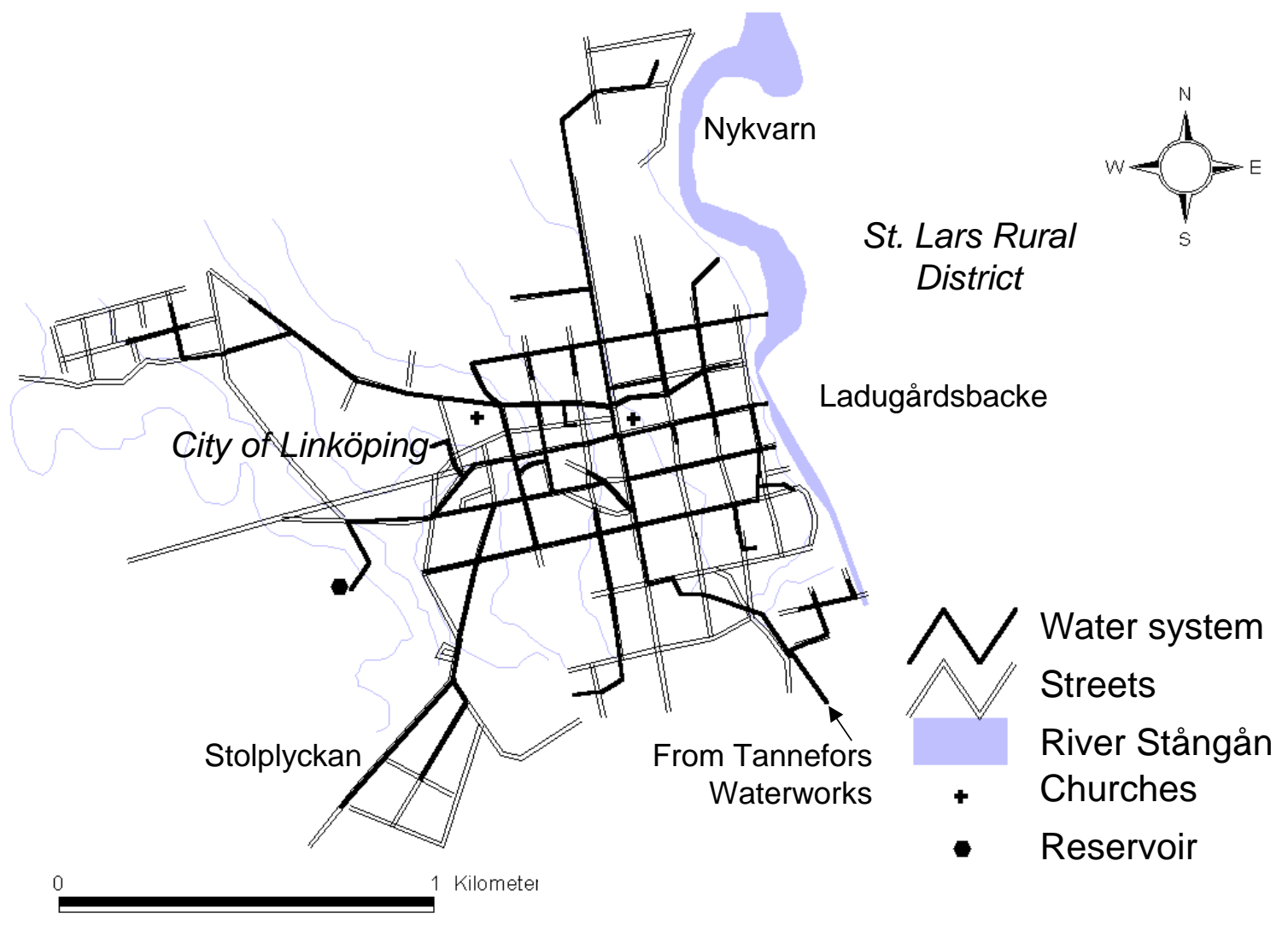

Figure 4: The Linköping water system in 1900. The street network roughly corresponds to the planned area of the city of Linköping (Sources: Schmid and Hallström, 'The pipe-bound city in time and space'; Hallström, Constructing a Pipe-Bound City, 217).

Despite the fact that the studied working-class suburbs in, for instance, Norrköping, Stockholm and Malmö were situated in close proximity to the cities' planned areas and to communication systems such as roads and railways, they were thus not attractive areas for urban expansion due to their geographical and environmental disadvantages. The city of Göteborg, on the other hand, included the working-class suburbs Masthugget and Majorna into the planned area and the original water system as early as 1872 . The main reason for this was that these areas were considered necessary for the future commercial and industrial growth of the city - they both lay near the harbour, which was essential for the city's commercial life. ${ }^{61}$

\footnotetext{
${ }^{61}$ H. Bjur, Vattenbyggnadskonst i Göteborg under 200 år (Göteborg 1988), 37-61. Cf. R. Bågenholm, Min barndom i Majorna (Göteborg 1955) and A. Rosén, Det forna Majorna i ord och bild (Göteborg 1940).
} 
Secondly, there were technical considerations involved in an extension. The capacity of the existing water system was crucial, but because it was difficult to assess the exact range of future extensions within the new area the current capacity was open to differing interpretations. The Linköping Water Company and the City Council thus made very different estimates of the capacity of the waterworks in 1881, as did the debating council members in Norrköping in 1886, and it is very difficult to say who was right. Water consumption in both cities had been soaring ever since the beginning, but technical measures could be taken to increase water production with the available system. At any rate, what seemed to be feasible from a technical standpoint may not have been so easily solved when considering other factors. Technology was embedded in a social context.

Thirdly, economic factors were always very important when deciding whether to extend a water system or not. In the case of these working-class suburbs it was uncertain to what extent the respective cities could make ends meet as regards the finances. Since mostly poor people and workers lived there, the capacity of paying taxes in general and water fees in particular was low. ${ }^{62}$ In Linköping the city was not as optimistic about the future economic sustainability of the extension as the Water Company was. Actors in both Linköping and Norrköping also feared either that the suburbs would demand more urban services and/or that other similar areas around the cities would request piped water, should Ladugårdsbacke and the northern suburb receive water pipes. It is likely that economy was a key factor behind the restrictive policies concerning water to the suburbs even in Malmö and Stockholm.

Fourthly, sanitary aspects of a water extension were considered in both Linköping and Norrköping. In Linköping, for instance, council member Nils Östling thought that piped water would not benefit Ladugårdsbacke from a sanitary viewpoint. On the whole, there were few

\footnotetext{
${ }^{62}$ In the northern suburb there existed illegal water taps, which also indicates that many inhabitants could not afford their own service pipes and the water fees: Hallström, Constructing a Pipe-Bound City, 188-9.
} 
concerns about epidemics in Ladugårdsbacke, maybe because the river separated it from the city and the fact that the suburb Stolplyckan to the southwest caused greater sanitary concern. Part of its drainage flowed into the city (see Figure 4).

In Norrköping some council members were of the opinion that water would even worsen sanitary nuisances, due to the poor drainage in the northern suburb. Yet the fear of epidemics originating in the northern suburb was very widespread in the Norrköping City Council since many of the suburb's inhabitants worked in the city. This was probably one reason why the suburb eventually received a water pipe, though on condition that drainage was improved first.

Finally, from an ideological point of view, a bourgeois definition of the urban space was also crucial. During the period from 1860 to 1890 an urban working class was forming in Sweden, and, just like on the Continent and in Great Britain, there was a fear of revolts, immorality and disease emanating from working class districts and suburbs. ${ }^{63}$ In Norrköping and Linköping, as well as in Stockholm and Malmö, it is likely that this fear also played an important part in the treatment of the suburbs, and thus the respective city governments sometimes displayed a very negative attitude to workers and their housing areas. Denying working class suburbs water and other services may have been a way of handling this fear by keeping the workers and the problems associated with them out of the city, the urban space.

In Norrköping there was a condescending, yet also very ambivalent, attitude to the workers, as in the metaphors of 'growth' and 'weed'. The bourgeois city fathers of Norrköping had a relationship to the workers and therefore, in the opinion of several council members, a sense of moral responsibility, which was why the northern suburb eventually

\footnotetext{
${ }^{63}$ C. Hamlin, Public Health and Social Justice in the Age of Chadwick: Britain, 1800-1854 (Cambridge 1998);

C. Prendergast, Paris and the Nineteenth Century (Oxford 1992); Johansson, Stor-Stockholms bebyggelsehistoria; O. Wetterberg, 'Renhållning', Bebyggelsehistorisk tidskrift, 44 (2002).
} 
received the short water pipe that was debated in $1886 .{ }^{64}$ The aristocratic and bourgeois elite in Linköping did not have such a complex relationship to the working class as did the bourgeoisie in Norrköping. To the extent that such a class existed in Linköping it lived and worked mainly outside the town, and the city was thus not as dependent on workers as Norrköping. Ironically, this may have made it easier to deny Ladugårdsbacke water so consistently, by referring to the legal power of the city border.

In Malmö and Stockholm there were also powerful people who actively worked to drive workers out of the central part of the cities, and thereby to exclude them from the urban space. One of the motives behind the first Stockholm water system, which was completed in 1861, was that it would make it possible to tear down dilapidated housing and clear up slums, so that workers could be relocated to other, peripheral parts of the city. Other city planning questions from late nineteenth century Stockholm confirm that some representatives of the bourgeoisie associated the working-class districts with poor sanitation and immorality, and therefore wanted to drive them as far from the city centre as possible. ${ }^{65}$ The working-class suburbs around the city of Stockholm were also denied water consistently.

\section{Conclusions}

In this article the extension of water to working class suburbs has been studied for two Swedish cities in particular, Norrköping and Linköping, but the primary material has also been complemented with secondary material from Malmö and Stockholm. When looking at why the working-class suburbs were most often denied - and on one occasion reluctantly given - piped water at this time in Swedish history some factors stand out as particularly

\footnotetext{
${ }^{64}$ Hallström, Constructing a Pipe-Bound City, 170-203.

${ }^{65}$ F.W. Leijonancker, Förslag till vattenledning i Stockholm (Stockholm 1853); H. Sheiban, Den ekonomiska staden. Stadsplanering i Stockholm under senare hälften av 1800-talet (Lund 2002), 224-6.
} 
important. The disadvantaged geographical location and poor topography of these suburbs were a drawback for them when extending water from the cities' piped water systems was discussed. Poor drainage, for example, was used as a direct argument against the extension of water, because the increased input of water could not be efficiently drained. Limited technical capacity of the whole urban system was also often seen as an obstacle to extension by city governments. However, the view of the capacity could differ considerably as there was no absolute way of measuring either technical constraints or future loads on the system.

For the Swedish cities in this study the extension of infrastructure to a suburb also potentially meant some kind of responsibility for the new area. This was an economic burden that they often would not carry, especially since the future of the suburbs was uncertain as regards, for example, tax- and water fee-paying capacity. In this sense the existing economic geography was confirmed even more with the question of extending urban sanitary infrastructure; those who could not afford it had to do without. One notable exception is Norrköping, whose Waterworks Board finally built a 200 metre pipe after a long council debate in 1886 . In this case it was probably the fear of epidemics on the part of the city that determined the question, since the suburb lay near the city and its inhabitants worked in the city. The fear of an epidemic originating in a working-class suburb thus seems to have been related to its distance from the city.

The spatial perspective on urban social relations introduced by Lefebvre stresses that the underpinning of social practices is spatial, and thus that space has social connotations. ${ }^{66}$ Each of these contributing factors - geography, technology, economy, sanitation and ideology had a spatial ring to it, and they all interrelated in space. The working class suburbs were located in geographically unfavourable places, to which extensions of water could be technically demanding, at least in the city governments' rhetoric, which also affected the

\footnotetext{
${ }^{66}$ Lefebvre, The Production of Space, 404.
} 
cities' economic considerations. Since the suburbs often lacked fiscal resources it was considered risky for the cities to finance the extensions, and the current economic geography was consequently underlined. Fear of epidemics prompted city governments to prioritize the well-being of the suburbs only when the city was threatened.

From Lefebvre's perspective urban, bourgeois ideology and practices resulted in a spatial exclusion of the suburbs, since water distribution during this period of Swedish urban history to a great extent seems to have been aimed at keeping workers out of the cities and prioritizing the cities at the suburbs' expense. In this sense, the difference between urban and suburban spaces was confirmed with water technology. Decisions not to extend water to poor, marshy, unproductive suburban land implied that piped water technology was primarily built for urban residents and spaces, thereby underlining already existing environmental and even spatial injustice between city and suburb. ${ }^{67}$

\footnotetext{
${ }^{67}$ The concept of environmental justice or equity has been used in a number of studies within the field of urban history in recent years, especially environmental history studies, and this article belongs to such a tradition. Cf., for example, R. Guha and J. Martinez-Alier, Varieties of Environmentalism: Essays North and South (London 1997); J.R. McNeill, Something New Under the Sun: An Environmental History of the Twentieth-Century World (New York 2000); M.A. Flanagan, 'Environmental justice in the city: a theme for urban environmental history', Environmental History 5, 2 (2000), 159-64; C.E. Colten, 'Basin street blues: drainage and environmental equity in New Orleans, 1890-1930', Journal of Historical Geography 28, 2 (2002), 237-57. However, by taking a spatial standpoint I believe that I have broadened the scope of the analysis beyond the purely environmental issues.
} 